Jurnal Ilmiah Al-Syir'ah Vol. 19, No. 1 (2021): 30-45

Website: http://journal.iain-manado.ac.id/index.php/JIS

ISSN 2528-0368 (online) ISSN 1693-4202 (print)

\title{
Study on the Causes of Inaccuracy of Qibla Direction of the Great Mosque Baitul Makmur West Aceh
}

\author{
Riza Afrian Mustaqim \\ Islamic State University of Ar-Raniry Banda Aceh, Indonesia, Lorong Ibnu Sina \\ No.2, Kopelma Darussalam, Kec. Syiah Kuala, Kota Banda Aceh, Aceh, 23111 \\ E-mail: riza.mustaqim@ar-raniry.ac.id \\ Reza Akbar \\ Islamic Institute of Sultan Muhammad Syafiuddin Indonesia, Jl. Sejangkung \\ Kawasan Pendidikan No.126, Sebayan, Kec. Sambas, Kabupaten Sambas, \\ Kalimantan Barat 79460 \\ E-mail: reza_akbar34@yahoo.com
}

\begin{abstract}
The accuracy of the Qibla direction at the Baitul Makmur Great Mosque in West Aceh cannot tolerate. The reason is that the value of deviation is so high that it does not face ainul ka'bah or even jihatul ka'bah. This Qiblah direction is not by the minimum limit of tolerance for the variation of the Qibla direction and is not by the Islamic legal status. This study examines the causes of the inaccuracy of the Qibla of the Great Mosque of Baitul Makmur Meulaboh West Aceh, namely the lack of role of figures and efforts to maintain the architecture of the mosque building. This research belongs to qualitative field research, by verifying the direction of the Qiblah with the rashdul qibla method and google earth observation to explore causes of inaccuracy. Interview techniques are also used to obtain in-depth field data. The analysis technique used is descriptive analysis. This study indicates that the inaccuracy of the Qibla direction of the Baitul Makmur Great Mosque in West Aceh is inseparable from the minor role of religious figures and leaders at the beginning of the Mosque's construction. Until now, the direction of the Mosque's Qiblah is still parallel to the mihrab. Renovations were also not carried out because of maintaining the architecture of the mosque building. Renovation of the mosque building to calibrate the Qibla direction would reduce the aesthetics of the mosque building.
\end{abstract}

Keywords: inaccuracy; Qibla direction; West Aceh; roles of figures and leaders; architecture. 


\section{Jurnal Ilmiah Al-Syir'ah Vol. 19, No. 1 (2021): 30-45 \\ Website: http://journal.iain-manado.ac.id/index.php/JIS ISSN 2528-0368 (online) ISSN 1693-4202 (print)}

\section{INTRODUCTION}

Facing Qibla in conducting prayer (shalat) is an important matter and is a complete sharia order. The jurists and all mujtahids agree that meeting the Kaaba in praying is obligatory and one of the requirements of a legitimate prayer (Akbar \& Asman, 2020). Because requirements must fulfil, it is not fair for someone (a Muslim) to pray while not facing the Qibla, except in some cases (Hambali, 2011). By the hadith of the Prophet Muhammad that if someone wants to pray, he is obliged to complete ablution and then face himself to the Qibla and then take Takbir (Bukhari, 1992).

The Syafi'iyah and Hanabilah scholars state that the obligation to face the Qibla for those who can see the Kaaba does not work unless they face 'ainul $k a^{\prime} b a h$ (the actual Kaaba). It means that this duty performed right up to the Kaaba. While the Hanafiyah and Malikiyah scholars state that for the people of Mecca who can see the Kaaba, they must face 'Ainul Kakbah, but for those who cannot see the Kaaba, it is enough to meet him to its direction or jihatul ka'bah (Labib, 2015). The Qibla direction is the direction or the closest distance along the great circle on the globe that passes through the city of Makkah (Kaaba) to a city or particular place (Hambali, 2011).

The Qibla direction of the Great Mosque Baitul Makmur Meulaboh is not facing the Kaaba, but rather the City of Alem Ketema, Ethiopia, which is about $1,400 \mathrm{~km}$ from the Kaaba. This inaccuracy observed by the annual Rashdul Qibla calibration that occurred on May 28 2019, where there was a deviation of the Qibla direction from the Kaaba to the South of 25 degrees (Observation of the Annual Rashdul Qibla, May 28 2019, 16.18 WIB in the courtyard of the Great Mosque of Meulaboh). Then the calibration using the azimuth Qibla method with a compass reference to the Qibla direction of the Great Mosque Baitul Makmur of Meulaboh shows a deviation of $-30^{\circ} 52$ ' 46.37 "to the South of the Kaaba. After being verified with the google earth software, this inaccuracy is factual.

The socio-religious problems of Qibla direction still become phenomena that can be found during society and potentially conflict. This problem happened in the Great Mosque of Demak, Central Java, Al-Ikhlas Mosque, Sejiram Sambas Village, West Kalimantan (Akbar \& Asman, 2020) several mosques, including the Baitul Makmur Mosque in West Aceh. Based on the above problems, it is necessary to trace the factors of deviation that happened till today (the initial measurement process of the Mosque's Qibla direction), in addition, to observe the Qibla deviation, so that it can be known the urgency of its calibration and the problems it causes.

Based on an interview with Tgk. Cut Usman, a religious figure or cleric in West Aceh, in general, local community leaders already know that the direction of the Qibla of the Great Mosque in West Aceh is not pointing in the Kaaba direction. However, for changing the direction of the Mosque's Qibla, the scholars 


\section{Jurnal Ilmiah Al-Syir'ah Vol. 19, No. 1 (2021): 30-45 \\ Website: http://journal.iain-manado.ac.id/index.php/JIS ISSN 2528-0368 (online) ISSN 1693-4202 (print)}

were divided into two groups. First, scholars agree to a change in the order of the Qibla. Scholars are aware of the inaccuracy of the Mosque's Qibla direction and want to calibrate the Qibla direction but do not have the authority to make such changes. Thus, their views are limited to providing input and suggestions without any follow-up. Second, the group of scholars who do not agree with the change in the direction of Qibla. In general, this group is also aware of the inaccuracy of the Mosque's Qibla direction, but on the other hand they also prioritize the presence of the congregation. They assume that a change in the Qibla direction will reduce public confidence, even raise doubts, and submit the question of how the previous prayers would have been if the Qibla was not in the direction of the Kaaba. To avoid this, this group tends to maintain the current Qibla direction.

\section{RESEARCH METHODS}

This research belongs to field research (Suryabrata, 1997) to examine the causes of Qibla's inaccuracy in the Great Mosque Baitul Makmur in Meulaboh, West Aceh, by tracing the history of measuring the Qibla direction that has carried out. To observe the deviation of the Qibla direction, the azimuth Qibla, global Rashdul Qibla, and google earth calibration methods are applied to calibrate the Qibla direction of the Mosque. To explore the causes of the inaccuracy of the Qibla direction, conducted by interview technique.

Primary data obtained from observation on the Qibla direction of the Great Mosque Baitul Makmur Meulaboh West Aceh is used to determine the Qibla direction's accuracy. The observation applied the azimuth Qibla and Rashdul Qibla methods. The tools used include: Mizwala as an ephemeris data processor mechanically and applied in determining the direction of the Qibla, then Google Earth as software for determining the latitude and longitude of a place and to describe virtual Qibla Direction so that the deviation is able to observe, and the Rashdul Qibla method. Interviews were also conducted to determine the history of measurement and the causes of the inaccuracy of the Mosque's Qibla direction. The secondary data in this research comes from library materials, including books, articles, and papers, as well as scientific journals and research reports related to the research.

In analyzing the data, verification analysis techniques were used by reexamining the current Qibla direction of the Great Mosque Baitul Makmur Meulaboh West Aceh. Then, data analysis by descriptive analysis to describe the causes of the inaccuracy of the Qibla direction of the Mosque. This kind of analysis technique is also called qualitative analysis (M. Amirin, 1995). 
Jurnal Ilmiah Al-Syir'ah Vol. 19, No. 1 (2021): 30-45

Website: http://journal.iain-manado.ac.id/index.php/JIS

ISSN 2528-0368 (online) ISSN 1693-4202 (print)

\section{RESULTS AND DISCUSSION}

\section{Methods in Determening Qibla Direction}

Historically, the method of determining the Qibla direction in Indonesia from time to time has developed by the development of knowledge and science possessed by Muslim people. At this time, the methods often used to determine the Qibla direction consist of two types, namely: the Qibla Azimuth Method and the Rashdul Qibla Method, also known as angle theory and the Sun shadow theory sequentially (Izuddin, 2012). The tools used to measure the direction also vary, such as bencet or miqyas or istiwa stick, rubu' al-mujayyab, compass, theodolite, and others (Ahmad, 2007).

\section{Qibla Azimuth Method}

Azimuth Qibla is the direction or angle measured from the North to the Kaaba clockwise (Khazin, 2004). To determine the azimuth of this Qibla some data are needed as follows:

a) Latitude and Longitude of a Place. The latitude of a place is the arc distance from the site to the equator measured along the longitude. The latitude value of a place ranges from $0^{\circ}$ to $90^{\circ}$. Latitude 0 o indicates that a place is on the equator. The South of the equator is called South Latitude with a negative sign (-), and to the North of the equator is called North Latitude with a positive sign (+).The longitude of a place is arc distance from a place to International Date Line or longitude line $0^{\circ}$ at Greenwich near London. Places to the west of Greenwich up to $180^{\circ}$ belong to West Longitude and is negative. At the same time, east of Greenwich up to $180^{\circ}$ belongs to East Longitude and is positive.

b) Latitude and longitude of Kaaba. The latitude and longitude of the Kaaba are the values of Latitude and Longitude exactly where the Kaaba place, namely at $21^{\circ} 25^{\prime} 21^{\prime \prime} \mathrm{N}$ dan $39^{\circ} 49^{\prime} 34^{\prime \prime}$ E. For both the Latitude and Longitude of a place and Kaaba, the data can obtain from the Global Positioning System (GPS) or Google Earth. Determining the Qibla direction is only a matter of direction, namely how every place on the Earth can determine its direction towards the Kaaba.

\section{Global Rashdul Qibla Method}

Global Rashdul Qibla is a time certainty in which the shadow of an object exposed to the Sun shows the direction of the Qibla. In general, the global Rashdul Qibla occurs on 27 or 28 May and 15 or 16 July, where these days are known as Yaumu Rashdil Qibla. On these two dates, the Sun's declination value is almost the same as the Latitude value of the Kaaba. Thus, if the Mecca time converts into Western Indonesian time, it must be added by 4 hours 21 minutes so that it becomes 16:18 and 16:27 Western Indonesian Time. Muslims can calibrate 


\section{Jurnal Ilmiah Al-Syir'ah Vol. 19, No. 1 (2021): 30-45 \\ Website: http://journal.iain-manado.ac.id/index.php/JIS ISSN 2528-0368 (online) ISSN 1693-4202 (print)}

the Qibla direction every 27 or 28 May at 16:18 WIB as well as every July 15 or 16 at 16:27 Western Indonesian Time. In some references, this Rashdul Qibla time can use for several days, ranging from 1 day before and one day after that date.

Besides being more accessible and can be done by everyone, the result of this method is more accurate. However, this method still has weaknesses. First, in terms of frequency in a year, this method can only be done for a minimum of two days, namely May 27 or 28 and July 15 or 16 . Second, in terms of geographic location, Indonesia, which is on the equator, causes our country to have a tropical climate with relatively high rainfall. As a result, applying this method in the field cannot be done when the weather is cloudy or rainy (Izuddin, 2012).

The techniques for determining the direction of the Qibla using the global Rashdul Qibla are followings:

a. Determine the location (house/mosque) that will be calibrated or the Qibla direction straightened.

b. Provide an upright stick or weighted string or pendulum.

c. Prepare a clock that has calibrated. It is preferable to use a digital clock that is connected online or standardized.

d. Ensure that a location that Qibla will be determined/calibrated has a flat field and exposed to sunlight at the time of the observation.

e. Wait until the time of global Rashdul Qibla comes. Observe the Sun's shadow hitting the stick/thread that gives a pendulum and mark it using a marker, nailed thread, duct tape, or other tools to draw a straight line.

f. Use a rope or string to straighten the Qibla direction to where the Qibla direction calibrated.

In Indonesia, the global Rashdul Qibla occurs in the afternoon so that the direction of the shadow goes to the east (backwards to the qibla direction). The opposite direction or the direction from which the image originates in the Qibla direction.

\section{Causes of Inaccuracy of Qibla Direction and Tolerance of Qibla Direction Deviation}

Errors in calculations and measurements or errors (deviations) caused by building construction (mosques). Qibla deviation in some mosques in Indonesia may also occur in other countries due to two possibilities. The first is that the direction of the mosques from the beginning is not in the right order to Qibla. The second is natural factors, namely the slow movement of the Earth's plate (Ngamilah, 2016).

According to Thomas Djamaluddin, the problem of inaccurate Qibla direction in many mosques is not a problem of shifting the Qibla focus. Still, because of incorrect measurements at the beginning of its construction. It is not a

Study on the Causes of Inaccuracy of Qibla Direction of the Great Mosque Baitul Makmur West Aceh 


\section{Jurnal Ilmiah Al-Syir'ah Vol. 19, No. 1 (2021): 30-45 \\ Website: http://journal.iain-manado.ac.id/index.php/JIS ISSN 2528-0368 (online) ISSN 1693-4202 (print)}

serious problem and is easy to correct. The Regional Hisab Rukyat Agency (BHR) of the Ministry of Religion and groups interested in rukyat reckoning can assist in refining the Qibla direction. Corrections collectively can also be done with a guide of the Sun's shadow when the Sun is above Mecca or with the Google Earth / Qibla locator, an internet-based Qibla direction guide. After the actual Qibla direction is obtained, the mosque building hasn't been reconstructed; just the row/shaf is adjusted. The Ministry of Religion, together with the Indonesian Ulama Council (MUI), BHR, Regional BHR, and groups interested in hisab rukyat can conduct socialization to the public about the adjustment of Qibla direction (Thomas, 2010).

Several factors that cause deviation of Qibla direction are followings (Maesyaroh, 2013):

a. The Qibla direction of a mosque is determined by an approach, namely by roughly referring to the Qibla direction of the existing Mosque. The mosque direction that uses as a reference is not necessarily accurate.

b. In some mosques, the direction of the Qibla is determined using less accurate tools.

c. Sometimes the determination of Qibla direction of a mosque is conducted by someone or figure who is prominent in the community. It is not sure that the figure can determine the Qibla direction correctly and accurately.

d. Before construction, the Qibla direction of a mosque had been measured correctly by experts. However, during the construction, the Qibla direction shift occurred without monitoring. This human error will certainly result in an imprecise Qibla direction that may even deviate significantly.

e. The opinion circulates among people that the direction of the Qibla is westward.

According to Thomas Djamaluddin, Qibla direction is unnecessary until the arc minutes because the inaccuracy of fewer than two degrees is still considered legitimate. For example, can be compared, two mosques side by side with a length of 10 meters, the deviation from Qibla at the ends is about $35 \mathrm{~cm}$. The congregation in the two mosques will look no different in direction. For the distance between Indonesia and Makkah, the difference of 2 degrees in Makkah is less than $300 \mathrm{~km}$. When viewed on a large globe, space is not too significant. That means, in determining the Qibla direction, an error of 2 degrees can still tolerate, considering that we can't keep our posture completely straight towards the Qibla. The congregation's direction in praying will not look different if the difference between the congregation is only a few degrees. It is possible that in very tight conditions (as is often the case in several mosques), the shoulder position is sometimes slightly tilted, the right shoulder is in front of the congregation on the right, the left shoulder is behind the congregation on the left. If we want to calculate carefully, it means a huge shift, about 20 degrees. Meanwhile, Islam does not make difficulties for the adherents (Thomas, 2010). 
Jurnal Ilmiah Al-Syir'ah Vol. 19, No. 1 (2021): 30-45

Website: http://journal.iain-manado.ac.id/index.php/JIS

ISSN 2528-0368 (online) ISSN 1693-4202 (print)

\section{Calibration of Qibla Direction of the Great Mosque Baitul Makmur of West Aceh}

In facing the Qibla accurately, the relationship between jurisprudence (fiqh), astronomy, and mathematics can understand in simple terms; namely, fiqh, which functions to grasp the sharia text, explains the obligation to face the Qibla in prayer. At the same time, mathematics functions to provide the calculation formulas and Astronomy functions to provide the data. Thus, the combination of mathematics and astronomy will produce provisions in which direction is right to face the Qibla (Miswanto, 2015).

Several methods have applied to calibrate and to ensure the inaccuracy of Qibla direction of the Great Mosque Baitul Makmur Meulaboh, including:

\section{Calibration using global rashdul qibla method}

The global Rashdul Qibla method accurately calibrates the Qibla direction (Izuddin, 2012). This method is the only method of determining the Qibla direction that is not dependent on Earth's shape. For areas near the Kaaba, determining the Qibla direction at the time of this event can be done quickly because the Sun is still quite high, for example, for Indonesia's western region (Akbar \& Mustaqim, 2020). The position of the Sun over the Kaaba can last from five to ten minutes. Observers who cannot precisely make their measurements on time can follow up for the next five to ten minutes (Maesyaroh, 2013).

Based on field observations, it was found that the deviation of the Qibla direction at the Great Mosque Baitul Makmur Meulaboh is very significant as following.

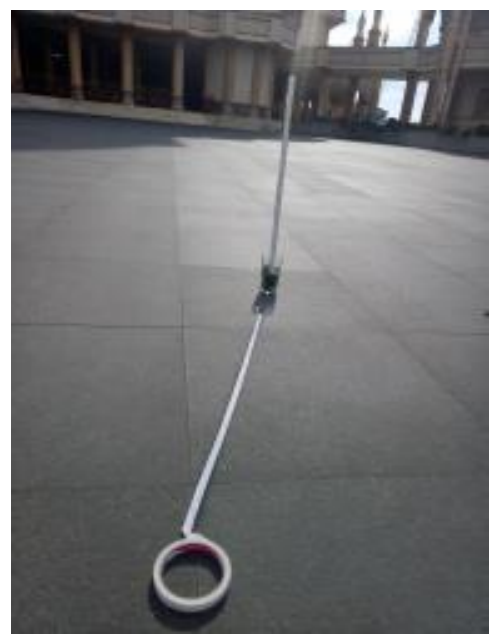

Figure 1. Qibla direction Calibration in Great Mosque Baitul Makmur Meulaboh using global rashdul Qibla method on May 282019

The figure above shows the direction of Qibla, which is parallel to the shaf in the Mosque. In contrast, the direction of the Sun's shadow marked with a 


\section{Jurnal Ilmiah Al-Syir'ah Vol. 19, No. 1 (2021): 30-45 \\ Website: http://journal.iain-manado.ac.id/index.php/JIS ISSN 2528-0368 (online) ISSN 1693-4202 (print)}

sellotape is the direction of the Qibla based on the global Rashdul Qibla that occurred at that time. After measuring the angle, the deviation of the Qibla direction of the Great Mosque Baitul Makmur Meulaboh reaches 20 degrees. If an extension is made to the Kaaba building from this deviation value, the deviation in the distance will be very far from the Kaaba.

In addition, the calibration carried out on May 27 2020, also showed the same result in which the angle of deviation from the Qibla direction of the Great

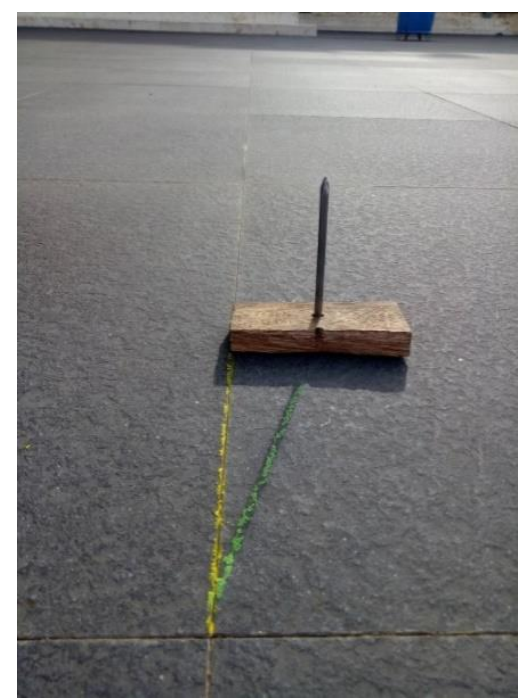

Mosque Baitul Makmur Meulaboh has the same value as the calibration in the previous year. The following showed:

Figure 2. Observation of Global Rashdul Qibla May 27, 2020 at Great Mosque Baitul Makmur Meulaboh

The figure above shows no significant difference regarding the observation results that show deviation of the Qibla direction at the Great Mosque of Baitul Makmur Meulaboh between the 2019 and 2020 observation. This repeated calibration offers the accuracy of the observations. This repeated observation is necessary so that there is no mistake or human error that can impact the validity of the data.

Based on the 2020 calibration above, there is a deviation of $20^{\circ}$ from the Kaaba. That means the Qibla direction of the Great Mosque Baitul Makmur Meulaboh leads far to the north side of the Kaaba. This deviation value cannot tolerate. Apart from being far from the Kaaba building ('ainul ka'bah), the Qibla direction of the Great Mosque Baitul Makmur Meulaboh also doesn't lead to Kaaba at all. 
Jurnal Ilmiah Al-Syir'ah Vol. 19, No. 1 (2021): 30-45

Website: http://journal.iain-manado.ac.id/index.php/JIS ISSN 2528-0368 (online) ISSN 1693-4202 (print)

\section{Calibration using Google Earth}

Google Earth is a virtual image of the actual Earth generated through satellite observations. Google Earth is a useful interactive mapping tool that allows the user to control a tilted perspective view of the Earth. This perspective view makes it possible to combine the three-dimensional features of the Earth's surface with the traditional two-dimensional map space. Google Earth users can view mountain ranges at an angle by controlling the viewing angle. It is also possible to enter buildings as 3-D objects. This data allows the user to view the three-dimensional cityscape. Nowadays, Google Earth is often used as a tool for detecting the location of a place, so that Google Earth can be used as a calibration for the Qibla direction as showed following:

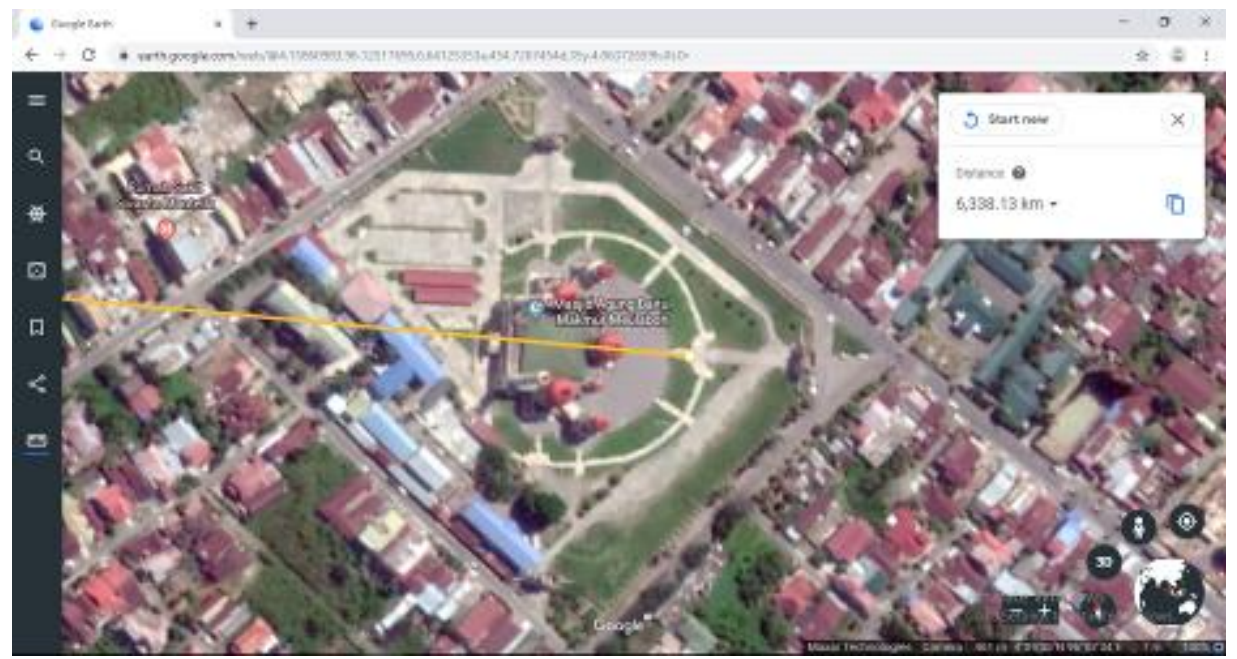

Figure 3. Qibla direction of The Great Mosque Baitul Makmur Meulaboh observed using Google Earth

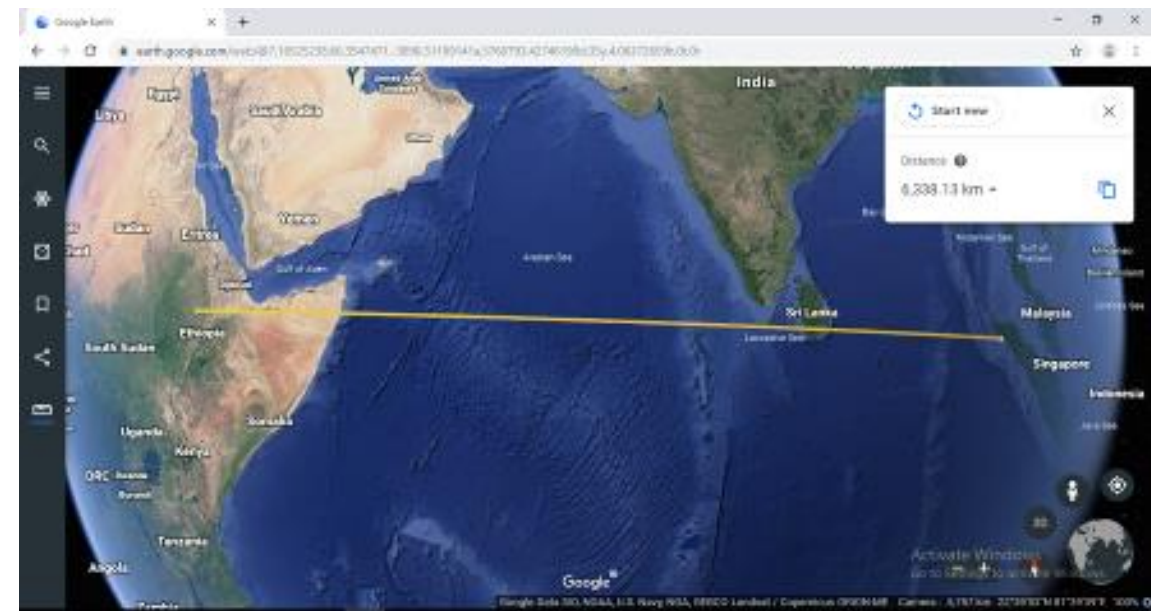

Figure 4. Qibla direction of The Great Mosque Baitul Makmur Meulaboh that lead to Ethiopia observed using Google Earth 
Jurnal Ilmiah Al-Syir'ah Vol. 19, No. 1 (2021): 30-45

Website: http://journal.iain-manado.ac.id/index.php/JIS ISSN 2528-0368 (online) ISSN 1693-4202 (print)

In figure 3, a straight line is drawn parallel to the Qibla direction of the Great Mosque Baitul Makmur Meulaboh. When the line extended, as seen in Figure 4, it turns out that the Qibla direction of the Mosque is pointing towards Ethiopia.

While the direction of the Qibla should be, when using Google Earth, it is shown as follows:

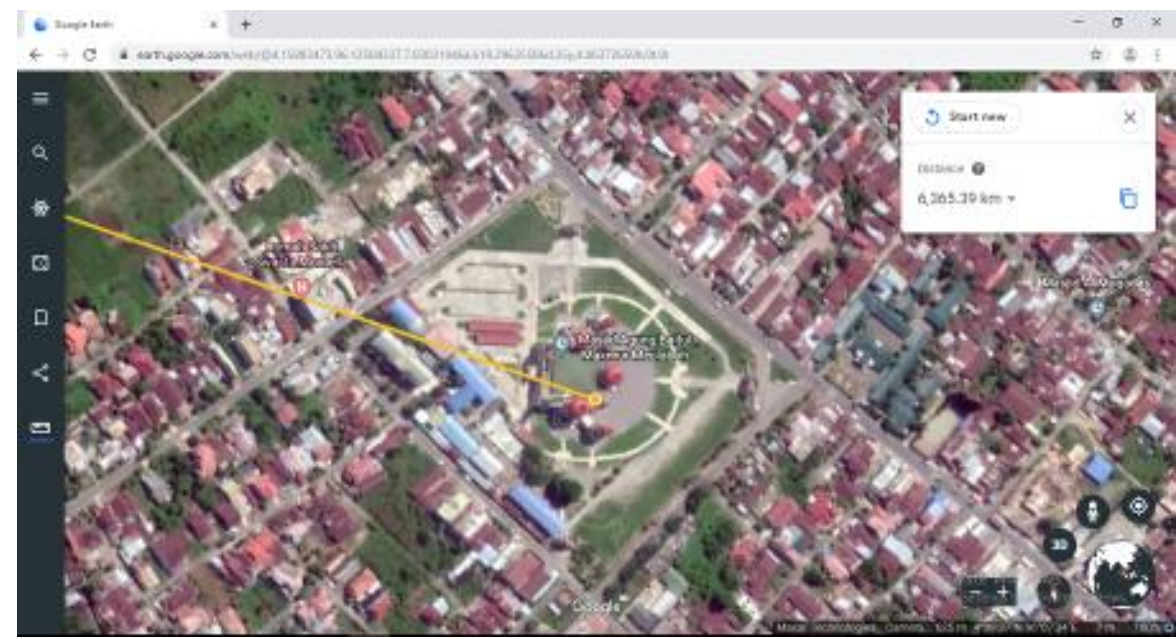

Figure 5. Qibla Direction of the Great Mosque Baitul Makmur Meulaboh, calibration result using Google Earth

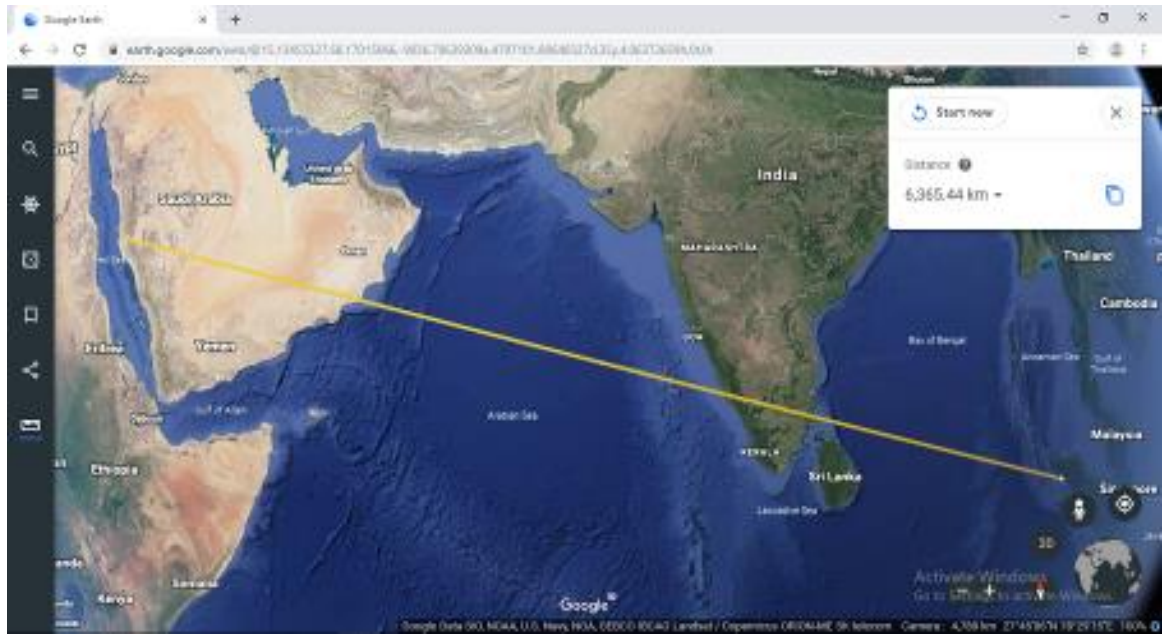

Figure 6. The Qibla Direction of the Great Mosque Baitul Makmur Meulaboh, the result of the correct calibration to the Kaaba, observed through Google Earth

In figure 5, a straight line is drawn that leads directly to the Kaaba building. When we look at Figure 6, there is a deviation towards the right side of the Mosque building from the Kaaba. This figure means that in calibrating Qibla direction using Google Earth, the Qibla direction of the Great Mosque also deviates. However, this inaccuracy can still tolerate. 


\section{Jurnal Ilmiah Al-Syir'ah Vol. 19, No. 1 (2021): 30-45 \\ Website: http://journal.iain-manado.ac.id/index.php/JIS ISSN 2528-0368 (online) ISSN 1693-4202 (print)}

\section{Calibration using Mizwala}

Mizwala is a tool for determining the Qibla direction practically using sunlight. The principle is the difference between Solar azimuth (that fluctuates by time) and Qibla azimuth. Determining the Qibla direction of Mizwala is by using sunlight, taking a shadow at the desired time. Then, the dial thread is rotated at the angle in the calculation result (the azimuth difference). The direction of the line is the direction of Qibla (Izuddin, 2012).

Based on the calibration of the Qibla direction using Mizwala, the angle of the deviation of the Qibla direction at the Great Mosque Baitul Makmur Meulaboh is almost the same as the calibration results using the two previous methods as shown the following:

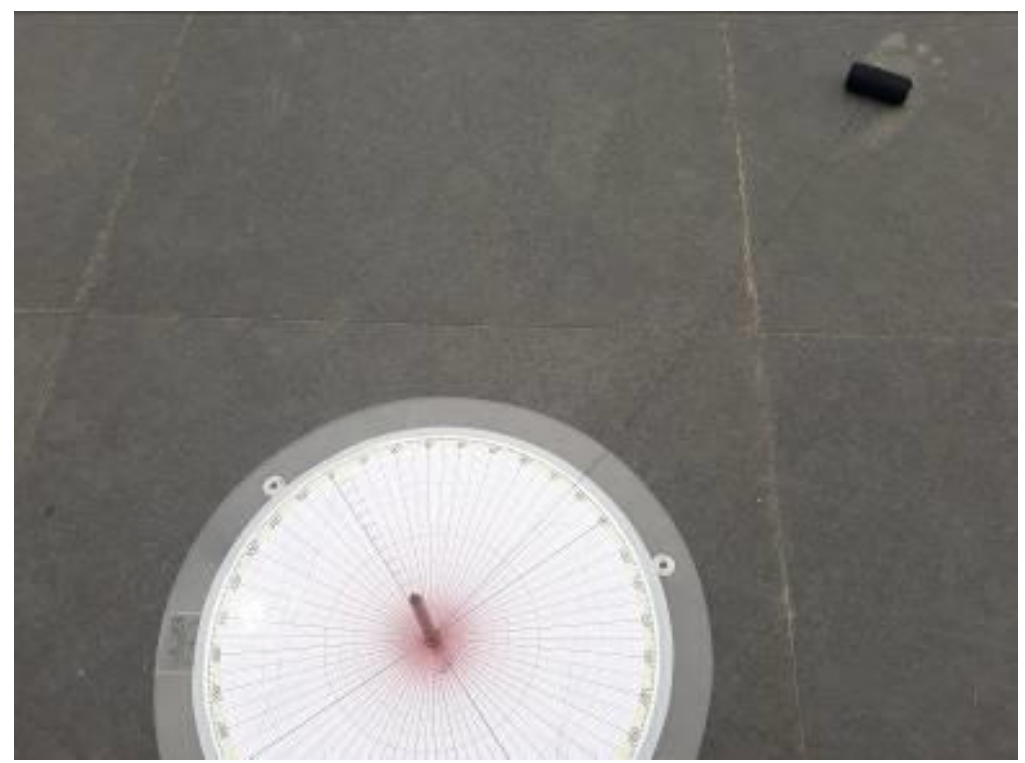

Figure 7. The Qibla direction of The Great Mosque Baitul Makmur using Mizwala

Based on the three methods above, the deviation of the Qibla direction is indeed significant at the Great Mosque Baitul Makmur Meulaboh. The three calibration methods above show that the Qibla direction of the Great Mosque Baitul Makmur Meulaboh deviates to the South of the Kaaba building by more than 20 arc degrees. Although the angle of deviation shown by the above methods is not correctly the same, a significant variation of the Qibla direction of the Great Mosque Baitul Makmur Meulaboh is evident.

According to Thomas Djamaluddin, in determining the Qibla direction, errors of up to 2 degrees can tolerate because, in the implementation of prayer, all worshipers can't maintain a correct posture towards the Qibla. In a very tight shaf condition as is often the case in several mosques, the position of one's shoulders is sometimes tilted slightly, one's right shoulder is in front of other's on the right, the left shoulder is behind another's on the left (Thomas, 2010). 


\section{Jurnal Ilmiah Al-Syir'ah Vol. 19, No. 1 (2021): 30-45 \\ Website: http://journal.iain-manado.ac.id/index.php/JIS ISSN 2528-0368 (online) ISSN 1693-4202 (print)}

Mohammad Awaluddin calculated the Kaaba to the side of Mecca, the accuracy of observing the Qibla direction from Indonesia ranges from $00^{\circ} 3 ' 22.8^{\prime \prime}$ to the North of Mecca and $00^{\circ} 2^{\prime} 16.33$ " to the South Mecca (Awaluddin et al., 2016). Meanwhile, according to Ismail, the tolerance for deviations from the Qibla direction for the city of Lhokseumawe is $0^{\circ} 24^{\prime} 31^{\prime \prime}$ (rounded to $0^{\circ} 25^{\prime}$ ) and can be used for the entire Aceh region. This data means that the Qibla direction of the Mosque is still accurate if the direction of the building is still within 25 minutes.

\section{Role of Religious Leaders}

Based on the findings in the field, local religious leaders played a minor role in determining the Qibla direction of Great Mosque Baitul Makmur. This role causes inaccuracy of the Qibla direction at the Mosque. According to Cut Usman, at the time of laying the Mosque's first stone in 1985, there was no actual measurement of the Qibla direction. Apart from the absence of experts in astronomy, there was also no special tool in determining the Qibla direction (Cut, 2019). Meanwhile, according to Syafruddin Kamil, one of the Hisab Rukyat team, West Aceh Regency, stated that initially, the Qibla direction of the Baitul Makmur Great Mosque was measured using a compass. However, at the time of building the mihrab, a human error occurred by the construction, causing the direction of the Qibla to shift (Kamil, 2019). At that time, measurement using a compass was sufficient because even though the direction was not pointing exactly to 'ainul $k a^{\prime} b a h$, it was pointing towards the jihatul $k a^{\prime} b a h$. This is evidenced by the Qibla direction of the Nurul Huda Mosque (the Great Mosque of West Aceh adjacent to the Baitul Makmur Grand Mosque), where the Qibla direction does not experience a significant shift from the direction of the Kaaba.

In general, the scholars of the Islam schools (mazhab) allow prayers to face the Kaaba direction absolutely (jihatul ka'bah). However, it is also necessary to pay close attention to the opinion of Imam al-Shirazi, who said: "If someone does not have any clues at all, then the maslahat will see. Suppose he is a person who knows the signs or directions of the Qibla. In that case, even though he cannot see the Kaaba, he still has to perform ijtihad to know the direction of the Qibla, because he has a way of knowing it through the existence of the Sun, Moon, mountains and wind. Allah SWT, said: "And (He created) signs (directions). And with the stars that they get guidance "(The Holy Quran, an-Nahl: 16) That way, he has the right to perform ijtihad in determining the location of the Kaaba like a person who understands natural phenomena." (Putra, 2015). The opinion of Imam al-Shirazi shows that there is a need to know the Qibla direction in the right direction if in an area there are people who are capable or understand in its determination. This form of effort in reaching the correct direction of the Qibla for people who are far from the Kaaba or cannot see the Kaaba.

Meanwhile, for those who cannot see the Kaaba, the Ulama have different opinions. First, the Syafi'i scholars argue that it is obligatory for those far from 


\section{Jurnal Ilmiah Al-Syir'ah Vol. 19, No. 1 (2021): 30-45 \\ Website: http://journal.iain-manado.ac.id/index.php/JIS ISSN 2528-0368 (online) ISSN 1693-4202 (print)}

Mecca to face 'ain al-ka'bah because, according to Imam Shafi'i, people who require meeting the Qibla means that they also oblige to face the Kaaba building like the residents of Mecca (An-Nawawi, n.d.). based on the QS. Al-Baqarah: 150. The verse obliges us to face the Kaaba, which means we must face the physical Kaaba as people who can see the Kaaba directly (Az-Zuhaili, 1991). Besides that, they based the hadith of Ibn Abbas (An-Nawawi, n.d.), which means:

"When the Prophet entered the Kaaba, he prayed all around and did not pray until he came out of it. He then prayed two rak'ahs looking at the Kaaba and said: This is the Qibla".

Second, most scholars other than Syafi'iyah believe that it is enough to face the direction of the Ka'bah (jihat al-ka'bah). The arguments put forward by the majority of scholars are the words of the Prophet. Narrated by Imam Ibn Majah and al-Tirmidhi, which reads:

"From Abu Hurairah said: The Messenger of Allah. Said, "What is between East and West is the Qiblah" (An-Nasa'i, 1999; At-Tirmidzi, 2003; Majah, 2004).

Outwardly, the hadith shows that all directions between the two, namely north and south, include the Qibla. Suppose it is obligatory to face the Kaaba physically. In that case, the prayers of people who are in long rows away from the Kaaba are invalid because they cannot ensure that their prayers face the physical Kaaba (Az-Zuhaili, 1997). Even though Muslims have agreed that their prayers are valid. After all, what is required for those who cannot see the Kaaba is to face the Ka'bah (jihat al-Ka'bah). (Majah, 2004).

This hadith is very relevant in Qibla direction at the Great Mosque Baitul Makmur Meulaboh in West Aceh. Moreover, experts in the field of astronomy in Indonesia are very capable of ensuring the accuracy of Qibla direction. Particularly in Aceh, Provincial and Regency Hisab Rukyat Agency (BHR) and Meteorology, Climatology and Geophysics Agency (BMKG) play an active role in measuring and calibrating the Qibla direction. In general, the BHR of West Aceh Regency plays a role in several things: Measuring Qibla Direction, Rukyatul Hilal, Preparation of imsakiyah schedules, Seminar for Ulema and Muslim Community, and Training on determining the Qibla Direction (Kamil, 2019). Thus, to reach the right direction to the Kaaba is not a difficult thing to apply to the Great Mosque Baitul Makmur Meulaboh.

The people of Aceh are indeed very well known as people who understand the application of Islamic law in the area. However, it should be understood that in Aceh, the understanding of Islam is very complex. In West Aceh, the knowledge developed is synonymous with Sufism, so it is not surprising if there are people who believe in a phenomenon. For example, many previous charismatic scholars in the southwest coast were able to perform Friday prayers in Mecca immediately, even though the Ulama was in Aceh. The local community

Study on the Causes of Inaccuracy of Qibla Direction of the Great Mosque Baitul Makmur West Aceh 


\section{Jurnal Ilmiah Al-Syir'ah Vol. 19, No. 1 (2021): 30-45 \\ Website: http://journal.iain-manado.ac.id/index.php/JIS ISSN 2528-0368 (online) ISSN 1693-4202 (print)}

believes this kind of thing. The understanding of Sufism is inherent to this day. If we relate it to the problem of the direction of the Qibla, the understanding that is developed is that when the heart is sure that it is facing the Kaaba, it is means we have met the Kaaba. On the other hand, the people of Aceh in the southwest have a very high patronage relationship with the Ulama. People tend to follow everything that conveys by their ulama, including the direction of the Qibla.

Rectification on the Qibla direction of the Great Mosque Baitul Makmur, West Aceh, is under the authority of the Mosque administrator, the Regent, and Regional People's Representative Assembly. It is not easy to change the direction of the Qibla at the Mosque without the consent of the parties. All parties must prioritize common interests rather than debate the sectoral understanding of each group. If the government understands the importance of facing the Qibla correctly, it is straightforward to change. The community for the change will also follow this.

\section{Maintaining the Architecture of the Mosque Building}

The Great Mosque Baitul Makmur Meulaboh has an exciting shape and architecture. Due to the considerable inaccuracy of the Qibla direction, the calibration (by renovating) would slightly change the aesthetics and beauty of the Mosque. Many things take into consideration in representing the Qibla direction of the Mosque. One of them is the mosque building itself. Is the calibration of the Qibla direction only done by simply shifting or changing the line (shaf)? Or must the building be renovated? These two questions are very important considerations. Regarding the change in the direction of the Qibla, it is about issues of belief and social problems.

Until now, the Qibla direction of the Great Mosque Baitul Makmur Meulaboh is still parallel to the direction of the mihrab. The mosque administrator also did not plan to renovate the mosque building to improve the direction of the Qibla by maintaining the aesthetically pleasing architecture of the mosque building. Renovating the mosque building to change the Qibla direction is considered to reduce the aesthetic of the mosque building. In addition, the mosque administrator has not made changes or calibrated the Qibla direction of the Mosque because it considers the comfort of the congregation, who is still challenging to accept the change, especially religious and community leaders who influence society. The calibration of the Qibla direction is straightforward to do without renovating the mosque building, namely by adjusting the direction of the line (shaf) to the right Qibla direction, which is not parallel to the mihrab. However, it turned out that this was not easy to do because a handful of worshipers who were influential figures in society still clung to zanni understanding of the Qibla (belief of guess). It means that they believe that the main thing in praying is solemnity. Changing the direction of the Qibla that is not following the mihrab would cause solemnity. Moreover, it is impossible to know for sure the direction of the Qibla because of its remote and invisible presence. 


\section{Jurnal Ilmiah Al-Syir'ah Vol. 19, No. 1 (2021): 30-45 \\ Website: http://journal.iain-manado.ac.id/index.php/JIS ISSN 2528-0368 (online) ISSN 1693-4202 (print)}

This kind of belief in the qibla zanni is no longer relevant today where there are practical and accurate methods of determining the Qibla direction.

\section{CONCLUSION}

The Qibla direction of the Great Mosque Baitul Makmur Meulaboh is proved not facing the Kaaba. This inaccuracy was observed by the annual rashdul Qibla calibration, using the azimuth Qibla method with a compass reference, and with the google earth software. The inaccuracy of the Mosque is inseparable from the lack of active role of religious figures and leaders at the beginning of the Mosque's construction. This role also has not shown any progress regarding the Qibla direction of the Mosque, so that maintaining the wrong Qibla direction still occurs. The administrator also did not plan to renovate the mosque building to improve the direction of the Qibla by maintaining the aesthetically pleasing architecture of the mosque building. In addition, the mosque administrator has not made changes or calibrated the Qibla direction of the Mosque because it considers the comfort of a handful of worshipers, especially community leaders who are still difficult to accept changes. On the other hand, the people of Aceh in the southwest have a very high patronage relationship with the Ulama. People tend to follow everything that conveys by their ulama, including the direction of the Qibla.

\section{ACKNOWLEDGMENTS}

Acknowledgments addressed to those interviewed, namely the administrator of the Great Mosque Baitul Makmur, for the willingness to provide the necessary research data and allow this research to carry out in the environment of the Great Mosque Baitul Makmur in Meulaboh, West Aceh.

\section{REFERENCES}

Ahmad, I. (2007). Fiqh Hisab Rukyah; Menyatukan NU \& Muhammadiyah dalam Penentuan Awal Ramadhan, Idul Fitri, dan Idul Adha. Erlangga.

Akbar, R., \& Asman, A. (2020). Social Conflict Due to The Controversy of Mosque's Qibla Direction in Sejiram Village, Sambas Regency. Jurnal Ilmiah Al-Syir'ah, 18(1), 1-12.

Akbar, R., \& Mustaqim, R. A. (2020). Problematika Konsep Bentuk Bumi Dan Upaya Mencari Titik Temunya Dalam Penentuan Arah Kiblat. Shar-E: Jurnal Kajian Ekonomi Hukum Syariah, 6(1), 43-52.

An-Nasa'i. (1999). Sunan an-Nasa'i (IV). Dar al-Fikr.

An-Nawawi. (n.d.). al-Majmu’ Syarh al-Muhadzab (III). Maktabah al-Irsyad.

At-Tirmidzi. (2003). Sunan at-Tirmidzi (I). Dar al-Fikr.

Awaluddin, M., Yuwono, B. D., \& Wicaksono, S. (2016). Kajian Penentuan Arah Kiblat Secara Geodetis. Teknik, 37(2), 84-87.

Az-Zuhaili, Wahbah. (1991). Tafsir al-Munir. Dar al-Fikr al-Mu'ashir.

Study on the Causes of Inaccuracy of Qibla Direction of the Great Mosque Baitul Makmur West Aceh 
Jurnal Ilmiah Al-Syir'ah Vol. 19, No. 1 (2021): 30-45

Website: http://journal.iain-manado.ac.id/index.php/JIS

ISSN 2528-0368 (online) ISSN 1693-4202 (print)

(1997). al-Fiqh allslami wa Adillatuh (I). Dar al-Fikr.

Bukhari, M. I. I. (1992). Sahih al-Bukhari. Daar al-Kutub al-'Ilmiyyah.

Cut, U. (2019). Interview.

Hambali, S. (2011). Ilmu Falak 1; Penentuan Awal Waktu Salat dan Penentuan

Arah Kiblat di Seluruh Dunia. Program Pascasarjana UIN Walisongo.

Ismail. (2020). Urgensi dan Legitimasi Fatwa Majelis Permusyawaratan Ulama Aceh Nomor 3 Tahun 2018 tentang Penetapan Arah Kiblat. Al-Manahij, 14.

Izuddin, A. (2012). Ilmu Falak Praktis; Metode Hisab-Rukyat Praktis dan Solusi Permasalahannya. Pustaka al-Hilal.

Kamil, S. (2019). Interview.

Khazin, M. (2004). Ilmu falak dalam teori dan praktik: perhitungan arah kiblat, waktu shalat, awal bulan dan gerhana. Buana pustaka.

Labib, M. (2015). Menghadap Qiblat Dalam Shalat. cilacap.kemenag.go.id. http://cilacap.kemenag.go.id/berita/read/menghadap-qiblat-dalam-shalat

M. Amirin, T. (1995). Menyusun Rencana Penelitian. PT. Raja Grafindo Persada.

Maesyaroh. (2013). Akurasi Arah Kiblat Masjid Dengan Metode Bayang-Bayang Kiblat (Studi Kasus di Kabupaten Garut). Istinbath; Jurnal Hukum Islam, 12(1).

Majah, I. (2004). Sunan Ibn Majah (I). Dar al-Fikr.

Miswanto, M. (2015). Telaah Ketepatan dan Keakuratan dalam Penentuan Arah Kiblat. Ta'allum: Jurnal Pendidikan Islam, 3(2), 229-243.

Ngamilah, N. (2016). Polemik Arah Kiblat dan Solusinya dalam Perspektif alQur'an. Millati: Journal of Islamic Studies and Humanities, 1(1), 81-102.

Putra, A. (2015). Cepat \& Tepat Menentukan Arah Kiblat. Penerbit Elmatera.

Suryabrata, S. (1997). Metodologi Penelitian. PT. Raja Grafindo Persada.

Thomas, D. (2010). Arah Kiblat Tidak Berubah. tdjamaluddin.wordpress.com. https://tdjamaluddin.wordpress.com/2010/05/25/arah-kiblat-tidakberubah/ 